\title{
Olhar e Espaço como Heterotopia na Pintura de Manet: uma Leitura de Michel Foucault
}

\author{
Rômulo Ballestê ${ }^{1}$ \\ Francisco Teixeira Portugal ${ }^{2}$ \\ ${ }^{1}$ Universidade Federal de Mato Grosso do Sul, MS, Brasil. $\quad \quad{ }^{2}$ Universidade Federal do Rio de Janeiro, RJ, Brasil.
}

Resumo: $\mathrm{O}$ artigo demonstra a dimensão heterotópica do olhar e do espaço próprios à pintura de Manet. O espaço, tal como concebido por Foucault, se constitui como poder-saber, e o olhar, tal como erigido pela pintura de Manet, visibiliza as heterotopias. A metodologia consistiu na seleção e análise crítica dos textos de Foucault sobre a pintura de Manet e a heterotopia acrescida de bibliografia de comentadores voltados para a análise da pintura, da arte e da heterotopia na obra do pensador. A raridade da reflexão sistemática acerca das considerações foucaultianas sobre a pintura e o espaço concebido como "espaço outro" faz com que a demonstração do entrelaçamento entre o espaço produzido pelas pinturas de Manet e a heterotopia configure novidade na literatura dedicada ao pensador. Concluímos indicando como as discussões estéticas estão indissoluvelmente ligadas às análises do poder. Neste caminho, Foucault indica, por exemplo, que a experiência da transgressão batailliana do olhar evidencia a condição da visualidade pictórica das telas de Manet. A visibilização dos efeitos políticos do espaço e seus outros assim como da produção artística pavimenta um caminho possível para esboçar novas compreensões das relações dos corpos com os enraizamentos espaciais e seus desdobramentos subjetivos singulares.

Palavras-chave: Michel Foucault, Olhar, Espaço, Édouard Manet, Heterotopia.

\section{Glance and Space as Heterotopy in Manet's Painting: a look on Foucault's interpretation}

\begin{abstract}
This article demonstrates the heterotopic dimension of glance and space in Manet's painting. Space, as conceived by Foucault, is constituted as power-knowledge, and glance, as defined by Manet's painting, reveals heterotopies. The methodology consisted in the selection and critical analysis of Foucault's texts on Manet's painting and the heterotopia plus bibliography of Foucault readers focused on the analysis of painting, art and heterotopia. The rarity of the systematic reflection of the Foucauldian reflections on painting and the space conceived as different space makes the demonstration of the interweaving between the space produced by Manet's paintings and heterotopia configure novelty in the literature dedicated to the thinker. We conclude by indicating how the aesthetic discussions are inextricably linked to the analysis of power. This path that Foucault indicates, for example, that the experience of Bataillean`s transgression of gaze evidences the condition of the pictorial visuality of Manet's canvas. The visibility of the political effects of space and other effects as well as of artistic production paves the way to sketch new understandings of the relationships of bodies with spatial roots and their unique subjective unfoldings.
\end{abstract}

Keywords: Michel Foucault, Glance, Space, Édouard Manet, Heterotopy. 


\title{
La Mirada y el Espacio como Heterotopía en la Pintura de Manet: una Lectura de Michel Foucault
}

\begin{abstract}
Resumen: El artículo pretende demostrar la dimensión heterotópica de la mirada y del espacio en la pintura de Manet. El espacio concebido por Foucault se constituye un poder-saber, y la mirada erigida por la pintura de Manet visibiliza las heterotopías. La metodología consistió en la selección y análisis crítico de los textos de Foucault sobre la pintura de Manet y la heterotopía, y en la bibliografía de comentaristas dirigidos al análisis de la pintura, del arte y de la heterotopía en la obra del pensador. La rareza de la reflexión sistemática de las reflexiones foucaultianas sobre la pintura y el espacio considerado como "espacio otro" hace que la demostración del entrelazamiento entre el espacio producido por las pinturas de Manet y la heterotopía sea una novedad en la literatura dedicada al pensador. En la conclusión indicamos cómo las discusiones estéticas están indisolublemente vinculadas a los análisis del poder. En este marco, Foucault apunta, por ejemplo, que la experiencia de la transgresión batailliana de la mirada evidencia la condición de la visualidad pictórica de los lienzos de Manet. La viabilidad de los efectos políticos del espacio y sus otros, así como de la producción artística, pavimenta un camino posible para esbozar nuevas comprensiones de las relaciones de los cuerpos con los enraizamientos espaciales y sus desdoblamientos subjetivos singulares.
\end{abstract}

Palabras clave: Michel Foucault, Mirada, Espacio, Édouard Manet, Heterotopía.

\section{Introdução}

Michel Foucault foi à Tunísia para assumir a cadeira de professor de filosofia em 1966 e lá permaneceu até o final de 1968, quando retornou a Paris. Em 1969 participou ativamente da formação do Departamento de Filosofia da Universidade de Vincennes (Paris VIII) e, a partir de 1971, ocupou o posto de professor do Collège de France. Ao longo deste período o pensador elaborou e destruiu alguns trabalhos sobre arte (Santos, 2011). Desde a História da loucura Foucault vinha alargando e borrando os limites disciplinares do pensamento filosófico ou científico incluindo trabalhos de literatura e de pintura (Calomeni, 2013, 2015; Foucault, 1963, 1966, 1963/1994, 1964/1994, 1966/1994, 1974/1994, 1975/1994b, 1989, 2014; Santos, 2011, Schapiro, 2003), e foi neste espírito que a conferência sobre o pintor Édouard Manet (1832-1883) foi preparada e apresentada na Tunísia em 1971 (Foucault, 1989).

No ano de 1966, na série radiofônica "Cultura francesa" sobre "utopia e literatura", o pensador apresentou uma ciência dos "espaços outros" sob o nome de heterotopologia, cujos princípios foram anunciados sob os títulos L'utopie du corps e Les hé térotopies. No ano seguinte, a convite do Círculo de Estudos Arquitetônicos, Foucault apresentou a conferência Des espaces autres, cujo texto datilografado transitou somente pela instituição responsável pelo convite (Defert, 2013). A autorização para a publicação de Des espaces autres na revista Architecture, Mouvement, Continuité ocorreu em 1984, quase vinte anos após a realização da conferência e pouco antes da morte do filósofo. Naquele momento, Foucault estimulou abertamente uma análise política e inovadora dos espaços, valorizando espaços outros.

A argumentação apresentada na emissão radiofônica sobre a heterotopia conecta-se à conferência sobre Manet em que a questão do espaço foi destacada. Ao se centrar na relação entre saber e poder produzida pelo espaço, o autor inscreve seus textos dirigidos à análise de artistas na questão do poder e articula intimamente estética e política.

O objetivo deste artigo consiste em demonstrar como o olhar e o espaço próprios à pintura de Manet constituem heterotopias. Defendemos a tese de que o espaço, no pensamento foucaultiano, se constitui como poder-saber e o olhar tornado 
possível ou erigido pela pintura de Manet visibiliza as heterotopias.

A análise de Foucault sobre o pintor está organizada em três rubricas para as quais um conjunto de quadros foi selecionado. A primeira rubrica diz respeito ao problema do espaço e utiliza as seguintes obras de Manet: La musique aux Tuileries (1862); Bal la masqué à l'Opéra (1873-1874); L'exécution de Maximilien (1868); Port de Bourdeaux (1871); Argenteuil (1874); Dans la serre (1879); La serveuse de bocks (1879); Le chemin de fer (1872-1873). O problema da luz é a segunda rubrica analisada e remete a um segundo conjunto de quadros, a saber: Le Joueur de fifre (1866); Le déjeuner sur l'herbe (1863); Olympia (1863); Le Balcon (1868-9). Por último, Foucault analisa o ponto de vista do observador a partir do quadro Un bar aux Folies Bergère (1881-1882)1. O espaço pictórico constituído pela ênfase do quadro concebido como uma superfície em relação com a iluminação, com o observador e compreendido como heterotópico indica, na medida em que interroga o espaço da experiência perceptual ordinária, outro espaço.

O procedimento utilizado para elaboração deste artigo consistiu na seleção e análise crítica dos textos de Foucault sobre duas questões "menores" em sua obra, a saber, a pintura de Manet e a heterotopia. Acrescentamos a este corpus textual a bibliografia de comentadores voltados para a análise da pintura, da arte e da heterotopia na obra do pensador. As análises sobre o legado foucaultiano raramente abordam de forma sistemática suas reflexões sobre a pintura e o espaço concebido como espaço outro. Além disso, o entrelaçamento entre o espaço produzido pelas pinturas de Manet e a heterotopia configura alguma novidade na literatura dedicada ao pensador.

As "obsessões espaciais" (Foucault, 1976/1994) de Foucault alcançam o fundamental: as relações entre o poder e o saber. Tais relações são espaciais e impõem como tarefa da heterotopologia pensar espaços outros: espaços discursivos que configuram saber-poder. O espaço produzido pela pintura de Manet, enquanto discurso, constitui uma heterotopia por problematizar os espaços da experiência perceptiva habitual existentes em nossa sociedade e por desencadear uma reflexão da política destes espaços em que nossa existência acontece. Para empreender a análise desta heterotopia será preciso investigar a pintura e a questão política implícita na produção do espaço pictórico.

Foucault elaborou recorrentes análises da pintura $^{2}$, mas a transcrição da pintura enquanto discurso prático na materialidade do espaço foi exposta brevemente em 1969 no final de A Arqueologia do Saber (2010). Ali, a possibilidade de engendrar uma análise arqueológica que ultrapassasse os discursos científicos e tornasse visíveis regularidades de um saber não circunscrito à epistemologia foi aventada. Para tanto, Foucault apontou para uma eventual investigação arqueológica da pintura. Longe de conceber uma psicologia da obra de arte ou mesmo das intenções, sentidos e emoções por trás dos traços e cores, a análise arqueológica teria outra finalidade. Em uma arqueologia da pintura:

Não se trataria de mostrar que a pintura é uma certa maneira de significar ou de "dizer", que teria a particularidade de dispensar palavras. Seria preciso mostrar que, em pelo menos uma de suas dimensões, ela é uma prática discursiva que toma corpo em técnicas e em efeitos. Assim descrita, a pintura não é uma simples visão que se deveria, em seguida, transcrever na materialidade do espaço. Não é mais um gesto nu cujas significações mudas e indefinidamente vazias deveriam ser liberadas por interpretações ulteriores. É inteiramente atravessada - independentemente dos conhecimentos científicos e dos temas filosóficos - pela positividade de um saber (Foucault, 2010, p. 217).

\footnotetext{
${ }^{1}$ Shapiro (2003, p. 321), seguindo proposta de Hollier sobre a complementaridade dos textos Raymond Roussel e o Nascimento da clínica, ambos de 1963, indica que as três rubricas - o espaço, a luz e o observador - estão presentes na arquitetura dos dispositivos disciplinares de poder como, por exemplo, no diagrama do Panopticon de Jeremy Bentham. A articulação destas rubricas com a arquitetura no poder disciplinar não será, contudo, objeto da nossa análise neste trabalho.

${ }^{2}$ É importante notarmos que a pintura aparece repetidamente nos trabalhos de Foucault embora nem sempre ganhe destaque no trabalho dos comentadores da sua obra. Vale destacar a análise meticulosa de Gary Shapiro (2003) das reflexões de Foucault sobre arte. Além das conferências sobre Manet, há as considerações bastante originais de Las meninas de Velásquez (Foucault, 1966), de René Magrite (Foucault, 2014), de Paul Rabeyrolle (Foucault, 1973/1994) e de Gerárd Fromanger (Foucault, 1975/1994a).
} 
Acrescentemos a esta proposta a compreensão de Rajchman (1988) de que a noção de visualização está articulada a uma ética na qual as pessoas agem e reagem em função de um modo de ver e pensar que se refere à tradição. Considerando também que Foucault tenha indicado que a pintura deva ser concebida como "uma prática discursiva" mas não tenha pavimentado este caminho, Rajchman propõe que para estudar os "eventos do visual" na história devemos pressupor certa regularidade que - em lugar da repetição - "abre a pintura à uma mudança e transformação, [e] as pessoas estão muito mais livres para pintar do que para imaginar" (Rajchman, 1988, p. 93).

Ao abordar a arte pictórica, Foucault se afasta, como de costume, da leitura dos aspectos comumente destacados pela historiografia das ideias. A importância de Manet para Foucault está em conceber o trabalho do pintor como uma intensidade que se realiza como discursividade. A obra de Manet institui um campo discursivo cuja potência foi considerada marco gerador da pintura moderna, operando um corte em toda tradição pictórica. A força da obra instaura um espaço não submetido ao domínio da representação, um espaço que não se orienta pelo artifício da similitude dos objetos da experiência. Diferindo desta prática, a obra de Manet produz um espaço outro, um espaço contra os espaços instituídos estética e politicamente em nossa sociedade.

\section{Pintura-objeto em Manet}

\section{Espaço e superfície}

A análise do espaço revela um jogo. Manet produz o espaço nas suas pinturas a partir de "um jogo que consiste em representar em uma tela as próprias propriedades de um trançar, o entrelaçar e a combinação do vertical e do horizontal" (Foucault, 2013b, p. 47). Este jogo de horizontais e verticais define certo plano na imagem.

Manet aborda o espaço nas suas pinturas, ao menos no primeiro conjunto de quadros analisados por Foucault, como repetição das duas dimensões da própria tela, da trama de fios que tecem o tecido, da borda, do limite e da moldura no interior da imagem por meio de um jogo dos eixos horizontal e vertical.

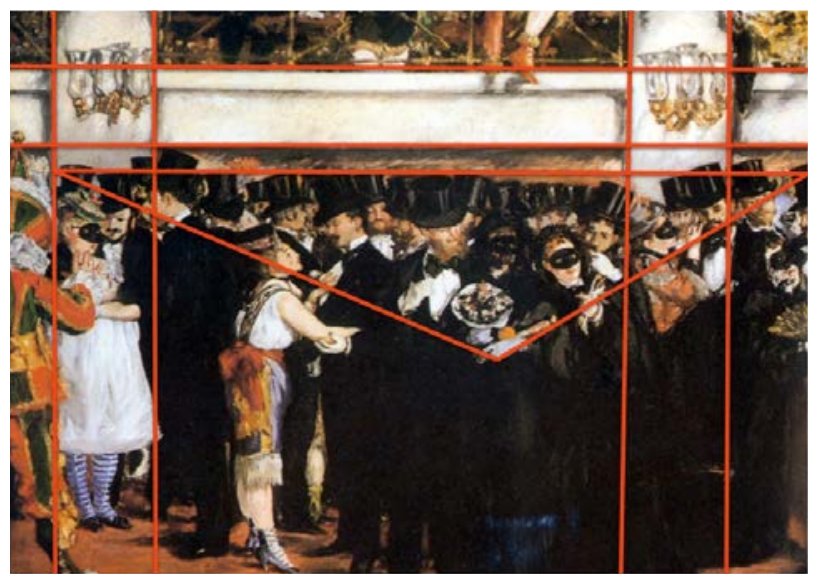

Figura 1

Edouard Manet, Bal la masqué à l’opéra (1873-1874). Óleo sobre tela, $59,1 \times 72,5 \mathrm{~cm}$.

Fonte: National Gallery of Art, Washington, DC.

A repetição das dimensões materiais da tela está articulada a outro aspecto da espacialidade: a compressão da profundidade. Em Bal la masqué à l'opéra (1873-1874) observa-se uma profundidade fechada por uma espessa parede em que nada há a ser visto além dela. No entanto, quando nos valemos dessa ideia de uma profundidade resultante da composição do jogo de horizontais e verticais, é possível inscrever a imagem como pintura-objeto e romper com a espacialidade construída pela técnica da perspectiva própria à pintura ocidental desde o quattrocento ${ }^{3}$.

A profundidade está comprimida, a distância entre o plano da superfície no qual as figuras estão localizadas e o espaço atrás dessas figuras é muito pequeno, dando a impressão de que a própria tela empurra as figuras para a frente em direção ao observador. Figuras geométricas fechadas em duas dimensões organizam essa ideia em algumas imagens do pintor. No primeiro quadro, La Musique aux Tuileries (1862), encontra-se um triângulo cujo vértice aponta para baixo e a base está paralela ao limite horizontal superior da própria tela.

\footnotetext{
${ }^{3}$ A concepção espacial própria ao Renascimento realiza-se a partir da perspectiva, a qual estabelece um ponto fixo e determinado para um espectador imóvel. A posição do espectador imóvel é determinada de antemão e suprime o próprio olhar do espectador na medida em que é concebido de maneira abstrata, como correlato de formalização. Portanto, quando a visão é estabelecida de antemão, por um espaço geométrico racionalmente organizado configurando a totalidade da imagem no espaço criado artificialmente na tela, o olhar não comparece. Os fundamentos teóricos desta concepção são desenvolvidos, pela primeira vez, no importante trabalho Da Pintura, de Alberti (2009).
} 


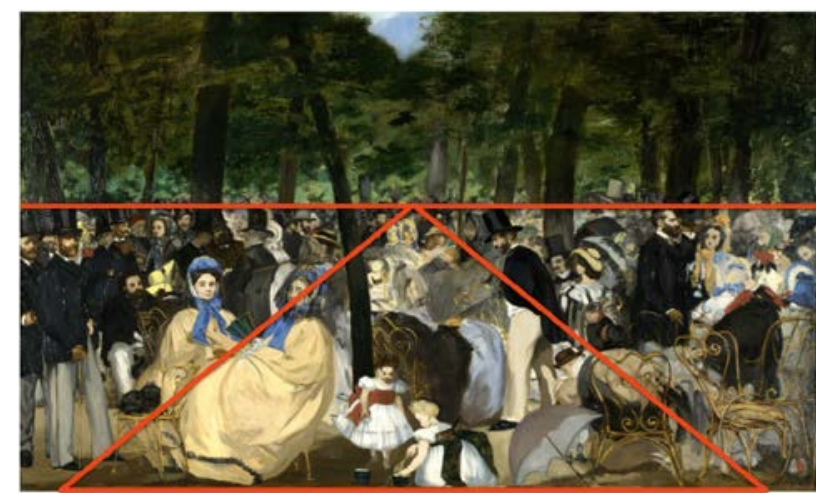

Figura 2

Édouard Manet, La Musique aux Tuileries (1862). Óleo sobre tela, $76,2 \times 118,1 \mathrm{~cm}$.

Fonte: National Gallery, Londres.

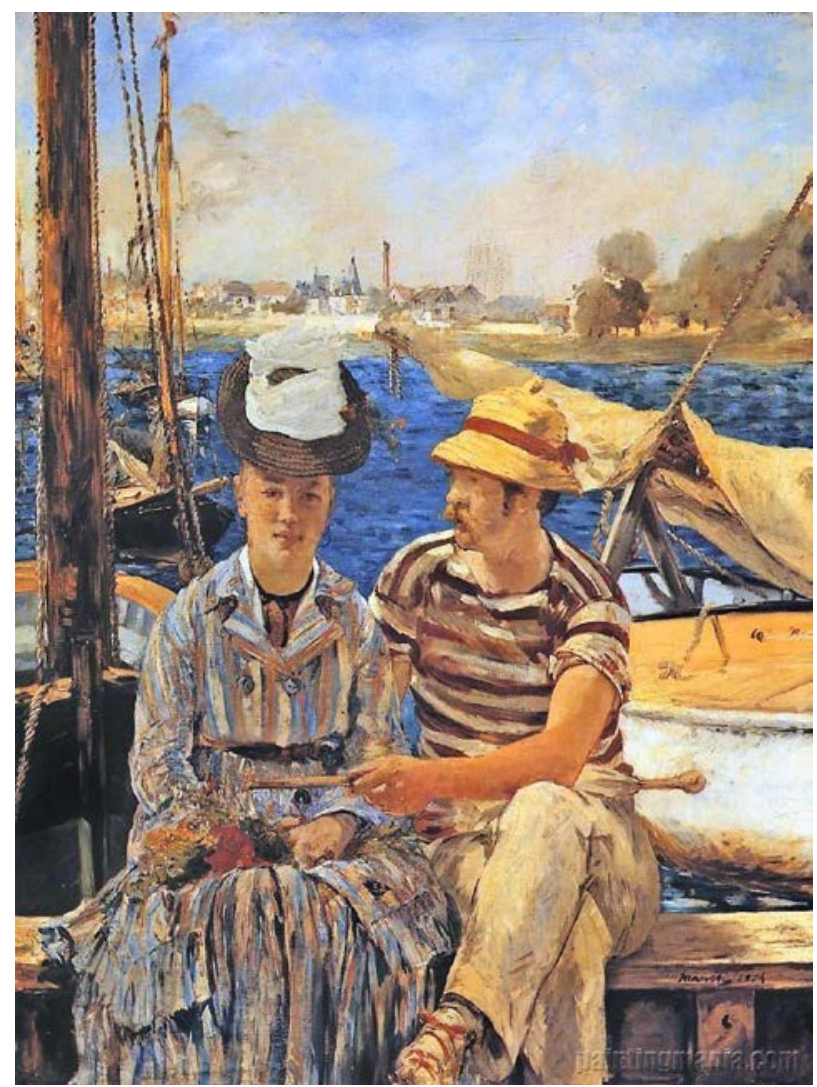

Figura 3

Édouard Manet, Argentuil (1874). Óleo sobre tela, $149 \times 115 \mathrm{~cm}$.

Fonte: Musée des Beaux-Arts de La Ville de Tournai, Bélgica.

No quadro Bal la masqué à l'Opéra (1873-1874), há um retângulo no interior da imagem - demarcado pelas duas pilastras nos cantos e a grossa barra horizontal no alto -, paralelo à conformação geométrica da superfície retangular da tela. O quadro L'éxécution de Maximilien (1868), por sua vez, apresenta uma sucessão de retângulos formados pelas vítimas e pelos executores em pé com os seus rifles em ângulo reto empunhados contra o peito. A distância, tornada pequena, entre executores e vítimas é preenchida por uma breve fumaça que sai dos canos praticamente no instante dos disparos à queima roupa. $\mathrm{O}$ alinhamento dos rifles comprime a imagem da cena que se passa em frente a um muro numa espécie de sequência de pequenas linhas retas horizontais e verticais, mais uma vez reproduzindo os elementos materiais bidimensionais. Esse jogo pictórico se faz presente também no quadro Argentuil (1874) pelo mastro à esquerda da tela, pelas linhas horizontais representadas pelo banco no qual o casal está sentado e pela linha verde que delimitaria a água e a cidade no alto da tela.

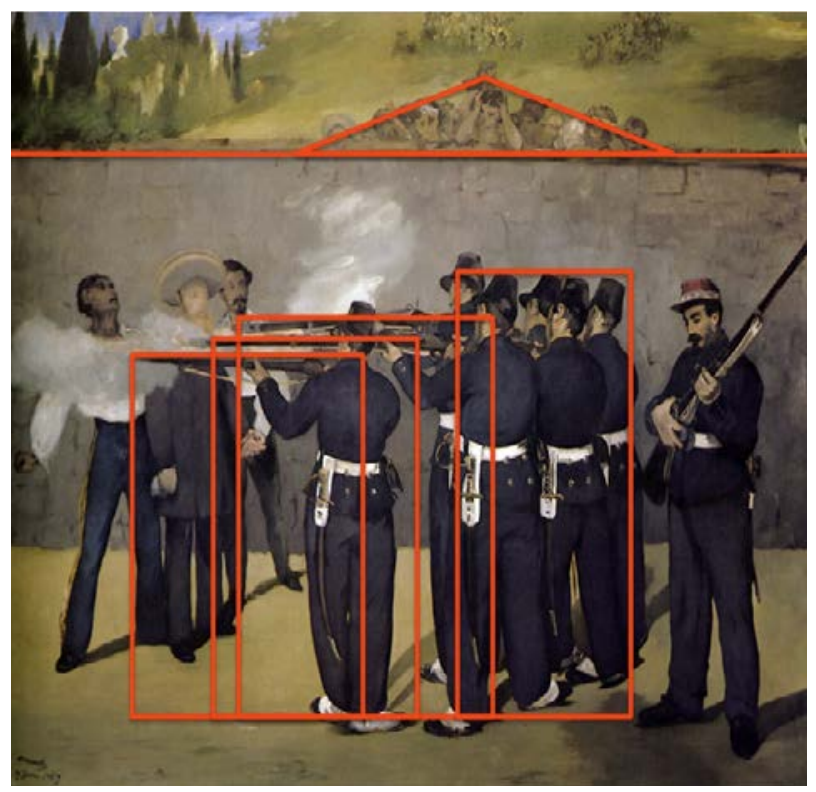

Figura 4

Édouard Manet, L'exécution de Meaximilien (1868). Óleo sobre tela, $252 \times 302 \mathrm{~cm}$.

Fonte: Kunsthalle Mannheim, Alemanha.

Este jogo das linhas verticais e horizontais marca, segundo Foucault, o nascimento da pintura abstrata conforme revelado novamente no quadro Port de Bourdeaux (1871). O ângulo reto formado pelo jogo das verticais e horizontais dos mastros reproduz os ângulos do contorno da própria tela. Foucault faz 
uma ligação estética entre o canto superior esquerdo do quadro de Manet, no qual figuram inúmeros mastros dos navios, e os quadros das árvores de Piet Mondrian $^{4}$ e de Wassily Kandinsky.

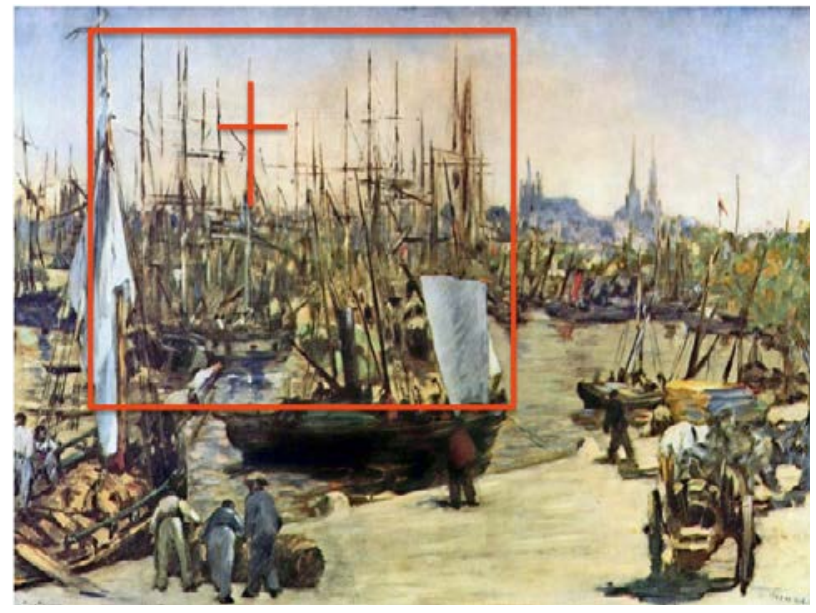

Figura 5

Édouard Manet, Port de Bourdeaux (1871).

Óleo sobre tela, $66 \times 99,5 \mathrm{~cm}$.

Fonte: Coleção privada, Suiça.

O jogo que comprime a profundidade evidencia a materialidade da tela não apenas como uma superfície, mas como uma superfície que possui um verso e um recto (Foucault, 2013b, p. 49). E essa superfície será atravessada, justamente nesse aspecto recto verso, pelo olhar.

A introdução da questão do olhar faz ver revelando que há algo invisível. A invisibilidade é um efeito da produção do visível. A afirmação de Foucault de que o quadro La Serveuse de Bocks (1879) não oferece nada a ver gera a pergunta: "Como é possível que uma pintura não tenha nada para se dar a ver?” (Foucault, 2013b, p. 49). Neste quadro evidencia-se o olhar, não o que os olhos da atendente, ou do homem no balcão, veem.

Nos quadros La Serveuse de Bocks (1879) e Le Chemin de fer (1872-1873) o olhar é colocado numa posição radicalmente diferente da maneira clássica de estabelecer a tridimensionalidade na imagem. No primeiro, a imagem apresenta duas figuras e cada uma tem o seu olhar dirigido para alguma coisa que não podemos ver. A garçonete não olha para as canecas de cerveja que segura porque há algo que a captura situado à direita do limite da tela. O homem sentado ao balcão também tem o seu olhar capturado por algo que se situa para além do limite esquerdo da tela. Estes olhares são capturados por um espetáculo que não é dado à vista, algo invisível, portanto, para o observador. No entanto, esta invisibilidade garante certa visibilidade imanente à própria tela que permite a autonomia da imagem. A articulação da invisibilidade com a visibilidade amplia a imagem para além dos limites do quadro. Este transbordamento inaugura um espaço em que estão inseridos a própria tela, a iluminação e o observador. Resumindo, a articulação do olhar das personagens no quadro com o do observador institui um novo espaço. Os olhares das personagens não respondem à similitude da representação, pois estão inscritos no vazio que ultrapassa tanto as delimitações materiais da superfície da tela como a concepção do observador como um sujeito limitado ao eu.

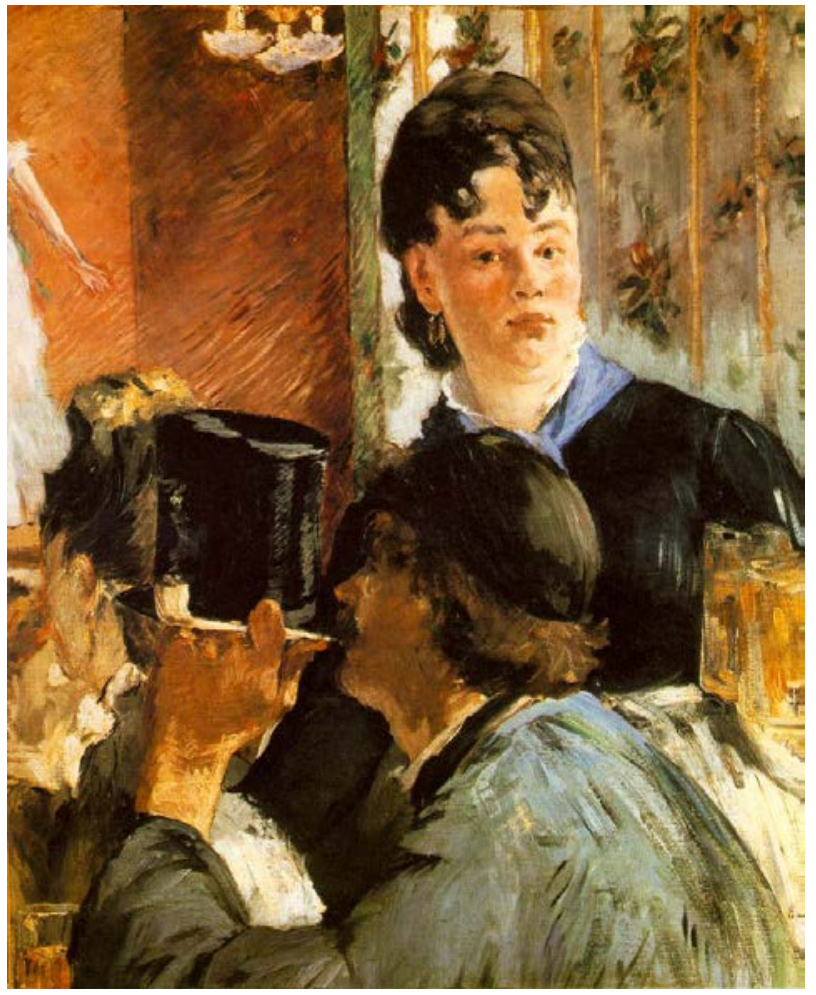

Figura 6

Édouard Manet, La Serveuse de Bocks (1879).

Óleo sobre tela 77,5 × $65 \mathrm{~cm}$.

Fonte: Musée d'Orsay, Paris.

${ }^{4}$ Podemos encontrar isto na análise feita por Meyer Schapiro: "Nos anos de 1914 a 1917, ele [Mondrian] pintou uma série de obras formadas por pequenas unidades verticais e horizontais, muitas delas tangentes ou cruzadas. Essas linhas ou barras pretas, mais gráficas do que pintadas, preenchem a superfície da tela de forma compacta. ... Nos títulos que Mondrian deu a algumas dessas pinturas. . . e nos traços de visão perspectivista, ele admite uma ligação com a percepção imediata da natureza” (Schapiro, 2011, pp. 247-248). 


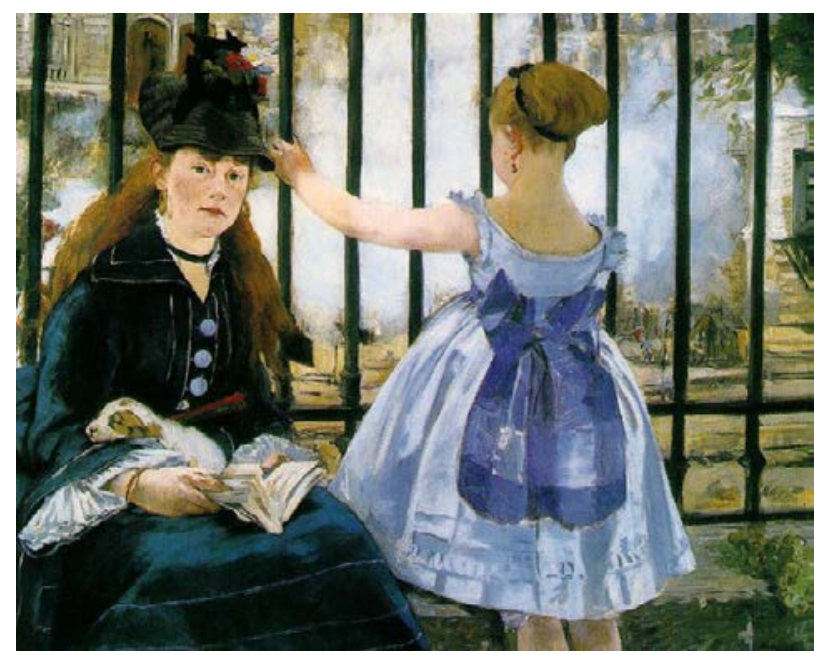

Figura 7

Édouard Manet, Le Chemin de fer (1872-3).

Óleo sobre tela, $93,3 \times 111,5 \mathrm{~cm}$.

Fonte: National Gallery of Art, Washington, DC.

A superfície em que estão as duas faces, recto e verso, não é um lugar onde uma visibilidade se manifesta: é o lugar que garante a invisibilidade do que é visto pelas figuras que estão no primeiro plano da tela (Foucault, 2013b, p. 53).

Em Le Chemin de fer (1872-1873), pode-se notar que cada personagem vê uma coisa que nós, como observadores, não conseguimos ver. A mulher sentada volta seu olhar para nós que olhamos para a tela mas, por outro lado, a menina volta o seu olhar na direção que nós, os observadores, olhamos. A repetição das linhas verticais e horizontais aparece mais uma vez reproduzindo a materialidade da tela, porém um novo elemento que escapou a Foucault pode aqui ser destacado. Se cruzarmos os eixos horizontal e vertical, encontraremos o eixo do olhar da mulher em composição com o olhar da menina evidenciando o recto-verso. Contudo, o olhar, pensado como um vetor, aqui não se sobrepõe aos eixos horizontal e vertical, pois, se assim o fosse, ainda estaríamos num plano cartesiano, num ponto zero (0) de interceptação dos três eixos. O olhar aqui opera como vazio produzido por um eixo ortogonal à tela. O olhar como vazio, como exterioridade ${ }^{5}$ que desfaz simultaneamente a consistência do sujeito da percepção e a unidade subjetiva sob a forma de um eu responsável pela observação, é o que permite tornar visível certa invisibilidade na medida em que produz um espaço no limite da linguagem e da representação no qual não há palavra a ser dita nem imagem a ser vista. Nesse sentido, não é uma espécie de segmento pontilhado, uma linha reta invisível que liga ininterruptamente os olhos do observador e o objeto visto. O olhar assim concebido difere, portanto, da visão e de sua estrutura geométrica de configuração que conhecemos pelo campo da óptica.

Encontramos certa conexão entre essa noção do olhar como vazio, situado no limite da linguagem e produtor desse espaço, e o olhar como transgressão - descrito por Foucault (1994a-1963) a partir dos textos de George Bataille. A força visceral dos textos de Bataille manipula a luz de um olho, rasga a carne e eviscera o globular olho soberano do sujeito. As questões que atravessam a literatura erótica pervertendo a estrutura do corpo, de modo a expor seu limite, são geradas no interior dessa força imanente. A experiência da transgressão enunciada por Foucault se configura pelo fato de estarmos situados no limite da linguagem - isto em decorrência da impossibilidade de inscrevermos a linguagem na palavra que, por natureza, ultrapassa todas as palavras e configura outro espaço. Nessa homenagem a Bataille (1963/1994), Foucault descreve duas formas de arrancamento do olho: o olho exorbitado, arrancado de sua órbita e eviscerado de qualquer olhar, e a de Bataille, o olho revirado.

Qualquer filosofia que tenha o olhar como fundamento para a obtenção da verdade pode ser chamada de reflexiva e está fundada em certo classicismo ou num racionalismo em que o olho se volta sobre si mesmo numa sucessão infinita de olhos que se alinham com o olhar e designam a verdade pela constituição do sujeito do conhecimento. Esses olhos voltados para seu interior constituem o lugar do sujeito soberano capaz de conhecer seguramente o mundo e, dessa maneira, encontrar a verdade filosófica. Por outro lado, a operação escatológica que reverte essa condição do sujeito com os olhos voltados para si mesmo, que arranca o olho de qualquer olhar, arranca simultaneamente, com este gesto, o sujeito filosófico de si mesmo. Na filosofia da reflexão, o olho se interioriza num movimento infinito até atingir como resultado do refinamento dos múltiplos olhos o ponto de pura transparência do olhar. O movimento

${ }^{5}$ Cf. La pensée du dehors (Foucault, 1966/1994), homenagem a Maurice Blanchot na qual Foucault desenvolve a noção de pensamento exterior. 
de autoquestionamento enfileira os olhares até chegar ao sujeito, sede ontológica das coisas não tangíveis do verdadeiro e momento de dissolução do olho anátomo-fisiológico.

O olhar transpondo o limite globular do olho o constitui em seu ser instantâneo. Nessa distância de violência e exorbitação do globo ocular, o olho é visto absolutamente, mas fora de qualquer olhar: o sujeito filosofante foi lançado fora de si mesmo, perseguido até os seus confins, e a soberania da linguagem filosófica é a que fala do fundo dessa distância, no vazio desmesurado deixado pelo sujeito exorbitado (Foucault, 1963/1994).

Ao revirar a órbita ocular e dirigir a íris para o interior escuro da cavidade craniana, a brancura do globo ocular transgride a abertura que antes era a própria fonte de transgressão. Se antes o olho lançava sua luz para as coisas da natureza e, assim, era capaz de conhecê-las, a luz do olho agora é derramada para a escuridão vazia do crânio. Os jogos entre o dia e a noite, entre a luminosidade solar e a obscuridade noturna estão presentes na imagem do olho revirado. Um movimento rotatório ocorre no globo de modo semelhante ao movimento da tela de Manet que gira evidenciando a sua natureza recto verso. O olhar é, portanto, entendido na análise foucaultiana da pintura de Manet sob a forma de um eixo (imaginário) que atravessa a tela. $\mathrm{O}$ eixo do olhar provoca o recto verso como efeito na superfície do quadro quando atravessa perpendicularmente a superfície. O globo ocular, ainda que permaneça no mesmo lugar, é arrancado com violência de sua posição voltada para o exterior. Dessa forma, podemos compreender que o olho revirado marca o limite. A operação de Bataille, que arranca o olhar do olho, está presente em Manet. Parece que o olhar em Manet já está desencarnado da brancura globular pela transgressão e não por causa do processo violento de exorbitação. Dessa maneira, o limite adquirido por meio da transgressão em Bataille já está colocado em Manet como condição da visualidade pictórica de sua obra.

Por fim, a pintura Dans la Serre (1879) é uma tela que contém claramente a maneira como Manet trabalhou o espaço. Como vimos nos dois últimos quadros, ele coloca o objeto visto na imagem fora do alcance do observador da tela. O olhar da mulher está mais uma vez voltado para algo fora da tela. Pode ser que não haja nenhum objeto a ser visto fora da tela, e seu olhar esteja numa articulação com a audição e não com a visão. No olhar articulado com a audição, olhar aparentemente blasé, o que a figura da mulher vê são as palavras dirigidas a ela pelo homem. Encontramos nesses três quadros, reiteradamente, divergência de olhares entre as figuras, seja o olhar do homem ao balcão do bar e o da garçonete que serve as canecas de cerveja, seja o olhar da menina voltado para além das grades da estação de trem e o olhar da mulher voltado para algo posicionado à frente da tela.

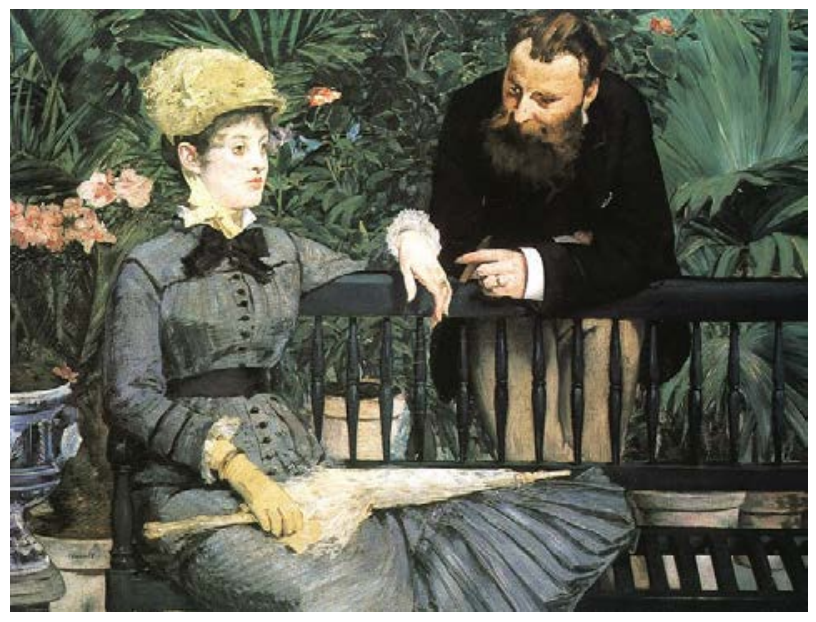

Figura 8

Édouard Manet, Dans la Serre (1879).

Óleo sobre tela, $115 \times 150 \mathrm{~cm}$.

Fonte: Nationalgalerie, Staatliche Museen zu Berlin.

\section{Luz e iluminação}

A segunda rubrica a que se dedica a análise de Foucault dos trabalhos de Manet envolve questões de iluminação e de luz. Como fizemos anteriormente, tomaremos alguns aspectos de sua análise articulando-os com a maneira como o olhar se inscreve na visualidade pictórica desses quadros.

No quadro Le déjeunuer sur l'herbe (1863), Foucault aponta dois sistemas de iluminação justapostos: uma iluminação frontal e perpendicular e outra iluminação tradicional, clássica e interior ao quadro cuja fonte de luz vem do alto e da esquerda. A iluminação clássica vem de cima e atinge o corpo nu da mulher sem modelar, sem conformar relevo algum. Essa iluminação clássica atinge as costas da mulher nua e o rosto dos homens sentados mas não molda suas feições. $\mathrm{O}$ alcance na totalidade da imagem está restrita a uma porção triangular deixando a relva como massas escuras. Ao mesmo tempo, uma mulher abaixada está iluminada acima da cabeça da figura do 
homem no centro da tela. É interessante notar que a iluminação tradicional não poderia iluminar essa mulher abaixada sem lançar luminosidade ao denso arbusto atrás dos corpos da mulher nua e do homem. Essa iluminação vem de fora e atinge perpendicularmente a tela. A justaposição das duas iluminações possui um caráter discordante, uma "heterogeneidade interna" (Foucault, 1989, p. 79) compondo uma mesma tela. Foucault afirma ainda que essas duas direções são apontadas pelos dedos da figura masculina na tela: uma direção da luz interior que vem de cima e de outro lugar, e o dedo curvado, dobrado, aponta a direção da origem da luz fora e que atinge perpendicularmente a tela.

A tela Olympia (1863) de Manet foi recebida com escândalo ao ser exposta pela primeira vez ao público. O escândalo moral que arrebatou a burguesia frequentadora dos Salões deve, para Foucault, ser entendido como um escândalo estético. O trânsito entre moral e estética decorre da questão da luz e da iluminação.

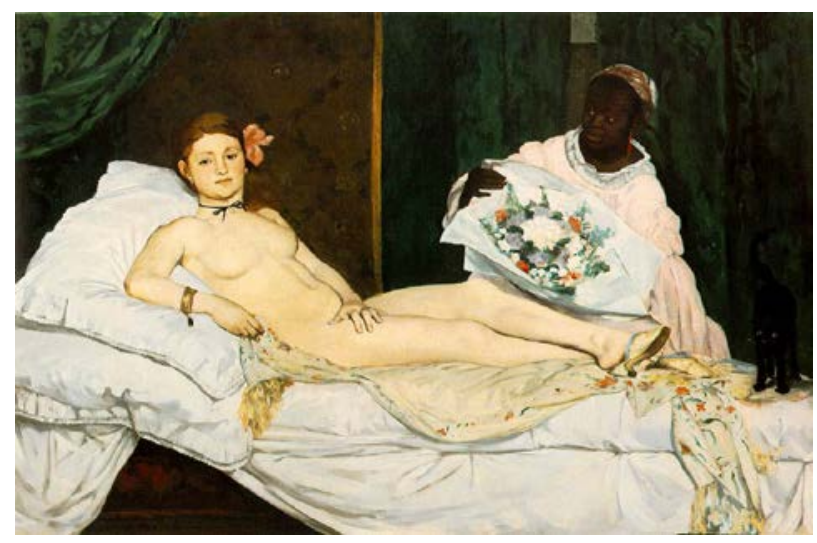

Figura 9

Édouard Manet, Olympia (1863).

Óleo sobre tela, 130,5 × $190 \mathrm{~cm}$.

Fonte: Musée d'Orsay, Paris.

Foucault observa que a escandalosa tela de Manet é uma duplicação, com diferenças importantes, da Venere di Urbino, uma tela de Ticiano Vecellio que data de 1583. No quadro do mestre italiano, uma jovem que representa Vênus e exibe seu corpo nu está deitada um pouco reclinada. Há uma leve luminosidade dourada que parte da esquerda do quadro e incide sobre o corpo da jovem. Tal luminosidade dourada é uma espécie de espaço dourado no interior da tela e é justamente este espaço, esta luz dourada, que toca sutilmente o corpo da jovem - porque a luz que acaricia Vênus, na tradição do quattrocento, é o princípio de visibilidade do corpo da jovem. A luz e a iluminação na pintura tradicional ocidental têm sempre a sua fonte e o seu sentido determinado pela construção geométrica da perspectiva. A iluminação é interior ao quadro e seu efeito é de modelar, dar relevo aos objetos e às figuras na imagem. Assim, a iluminação na tradição da pintura ocidental modela os corpos caindo levemente, delicadamente sobre o rosto da figura, o corpo de uma jovem ou uma paisagem gerando ao longo, e em consequência deste caimento, uma sombra que se desfaz harmoniosamente. Uma imagem, em suma, é representada em relação a uma fonte de luz com um sentido determinado e tem como efeito a modelagem do relevo no jogo de sombreamento.

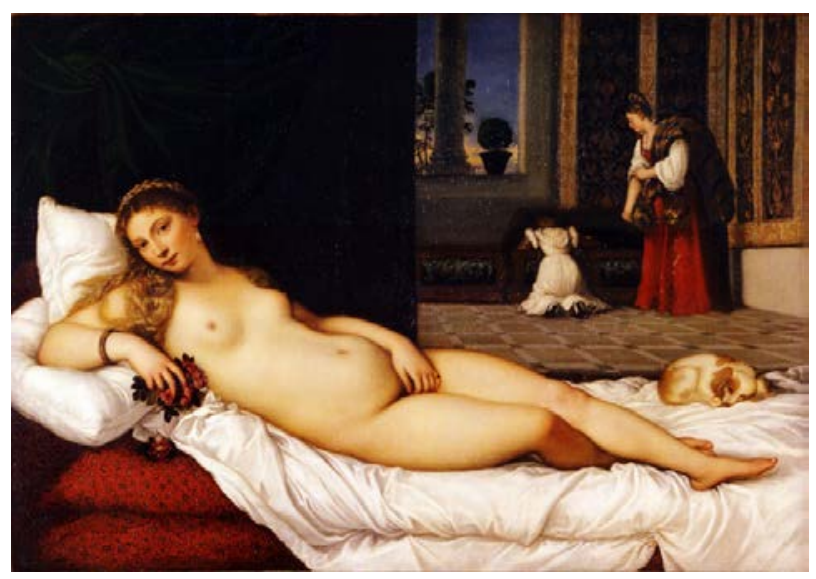

Figura 10

Tiziano Vecellio, Venere di Urbino (1538).

Óleo sobre tela, $119 \times 165 \mathrm{~cm}$.

Fonte: Galleria degli Uffizi, Florença.

Em Olympia (1863), a luz que atinge o corpo da jovem incide perpendicularmente à superfície da tela. É uma luz que vem de fora da tela, vem da frente da tela. Portanto, a condição de visibilidade em Manet é totalmente diferente da condição de visibilidade em Ticiano. Se este tem a visibilidade referida à luz e seu espaço, em Manet o que a compõe e possibilita não é este espaço produzido pela iluminação oriunda de um ponto representado na tela, pois não há tal espaço, mas a luz que atinge perpendicularmente a superfície material da tela - luz que possibilita a visibilidade ao revelar o jogo entre a nudez e aquele que se coloca diante da tela, isto 
é, o observador. Dessa forma, quem ocupa o lugar da luz é o próprio observador (Foucault, 2013b, p. 66).

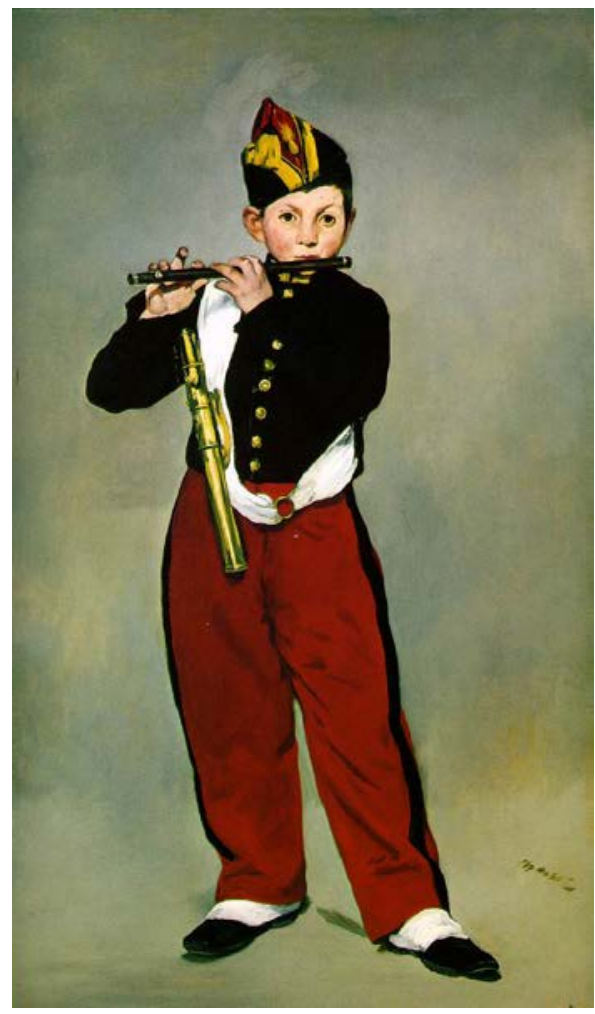

Figura 11

Édouard Manet, Le Joueur de fifre (1866).

Óleo sobre tela, $161 \times 97 \mathrm{~cm}$.

Fonte: Musée d'Orsay, Paris.

A iluminação no quadro do menino tocando pífano, Le Joueur de fifre (1866), representa uma modificação radical no sentido da iluminação na tradição ocidental. Foucault afirma que esta iluminação é anárquica, pois não há luz vindo de lugar algum. Não há nenhuma indicação, nenhum raio luminoso que insinue o sentido da luminosidade ou mesmo a fonte de luz. Para o pensador, a luz incide duramente sobre a superfície, razão pela qual não há modelagem ou relevo na face do menino, há apenas a indicação de seus traços. As únicas indicações da fonte luminosa são uma pequena sombra atrás do pé esquerdo do menino, a sombra do pífano que é projetada na mão direita e outra, bastante fraca, no talabarte branco próximo ao ombro. Novamente, vemos Foucault destacar a insistência de Manet na materialidade da tela a respeito da luz: "temos uma iluminação inteiramente perpendicular, uma iluminação que é a real iluminação da tela se a tela, na sua materialidade, fosse exposta a uma janela aberta, em frente a uma janela aberta" (Foucault, 2013b, p. 59).

Luz e observador bem como iluminação e olhar são os pares que se inscrevem no espaço aberto pela superfície da tela e que constituem a condição da visibilidade da nudez da imagem.

Ressaltamos que em Olympia há uma divisão vertical na tela que coloca uma figura de cada lado: a jovem branca exibindo a sua nudez, do lado esquerdo, e a mulher negra vestida com roupas brancas segurando um buquê de flores, do outro. Este traço vertical, ligeiramente dourado, compõe-se com a duplicação do eixo horizontal por algumas linhas que partem da lateral direita até um pouco além do centro da tela: aqui, mais uma vez, a insistência de Manet em reproduzir a superfície da tela nos seus aspectos bidimensionais se revela.

A ligação entre o olhar que substitui a iluminação e a nudez que se desdobra diante do observador implica o observador na visibilidade da imagem. Não foi a primeira vez que uma pintura que tem como tema a nudez feminina causou escândalo. $\mathrm{O}$ que faz a Olympia de Manet produzir um escândalo próprio é esta implicação do olhar e este efeito gerado pelo olhar do observador que revela e situa a nudez à sua frente. Dessa forma, para Foucault, tal implicação produz uma transformação, fazendo passar do domínio estético para o moral. O escândalo que ficaria restrito aos domínios do estético envolve, todavia, com Manet, o domínio social.

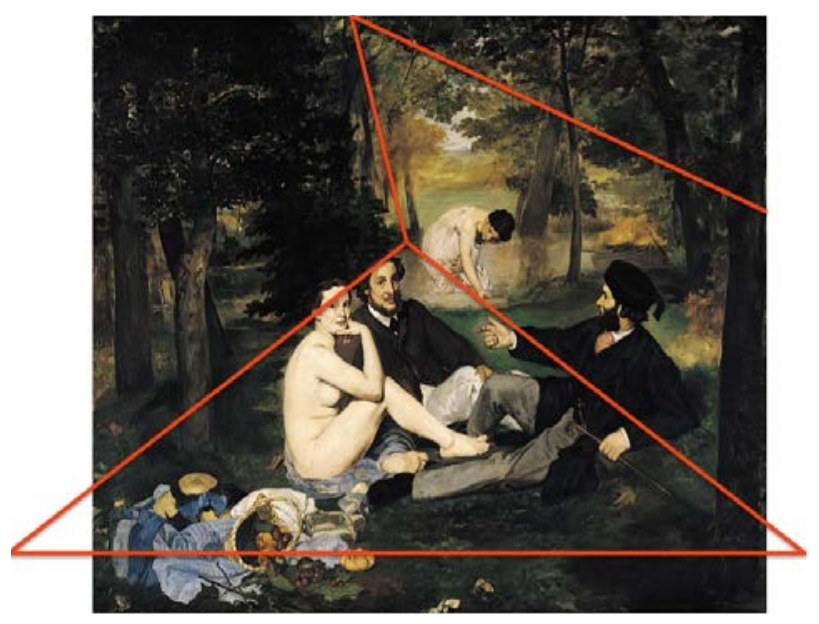

Figura 12

Édouard Manet, Le déjeunuer sur l’herbe (1863).

Óleo sobre tela, $208 \times 264,5 \mathrm{~cm}$.

Fonte: Musée d'Orsay, Paris. 
O último quadro analisado por Foucault neste segundo grupo relativo às questões da luz e da iluminação é o Le Balcon (1868-1869). Há nesta análise a combinação das duas espécies de questão. Neste quadro, encontramos mais uma vez os elementos imagéticos que constroem o espaço. As persianas verdes emolduram a imagem reproduzindo seus eixos. Além das persianas com suas numerosas treliças horizontais há ainda o gradeado de ferro verde da parte frontal inferior do Balcão composto por horizontais e verticais que reproduzem no interior da imagem o aspecto material da superfície da tela.

Os elementos que compõem a arquitetura do espaço pictórico são tradicionalmente dominados pela razão cromática do claro (branco) e do escuro (preto). Uma representação feita na obscuridade do sombreamento, na qual as figuras conduzem para as cores dos vestidos, drapeados de cores vibrantes, que assim contrastam fortemente com a alegoria arquitetônica ocultada pelo sombreamento. Foucault nos mostra que Manet inverteu esta forma tradicional. As três figuras que estão no balcão entre as persianas estão com vestidos brancos ou com tonalidades bastante claras, de certo branco intenso que os deixa lisos e em contraste com o negrume do quarto por detrás delas. Elas ocupam neste quadro a função dos elementos arquiteturais da pintura tradicional e as persianas verdes ocupam os vestidos que ornamentavam as damas. As figuras estão, portanto, na frente de um espaço praticamente vazio e inteiramente escuro. Para Foucault, o jogo que Manet produz com a profundidade é cruel, pois o pintor abre a janela e quando se adentra o fundo da sala cai-se abruptamente na escuridão.

Este espaço que Manet torna invisível ao observador está ligado à luminosidade. Toda luz está do lado de fora. Ela não penetra no interior da sala, pois incide de cima como a luz do sol ao meio-dia. Como as duas moças estão mais para fora do balcão, elas recebem esta luz de maneira intensa e direta. Esta luz não modela, consequentemente, muito bem as feições nem produz um balanço nos vestidos. A luz incidindo de cima faz com que toda a luminosidade esteja do lado de fora, ou melhor, na frente das figuras, e toda a sombra e escuridão do lado de dentro, atrás das figuras. A verticalidade da superfície da tela é responsável por separar a luz, na frente, e a sombra, atrás.

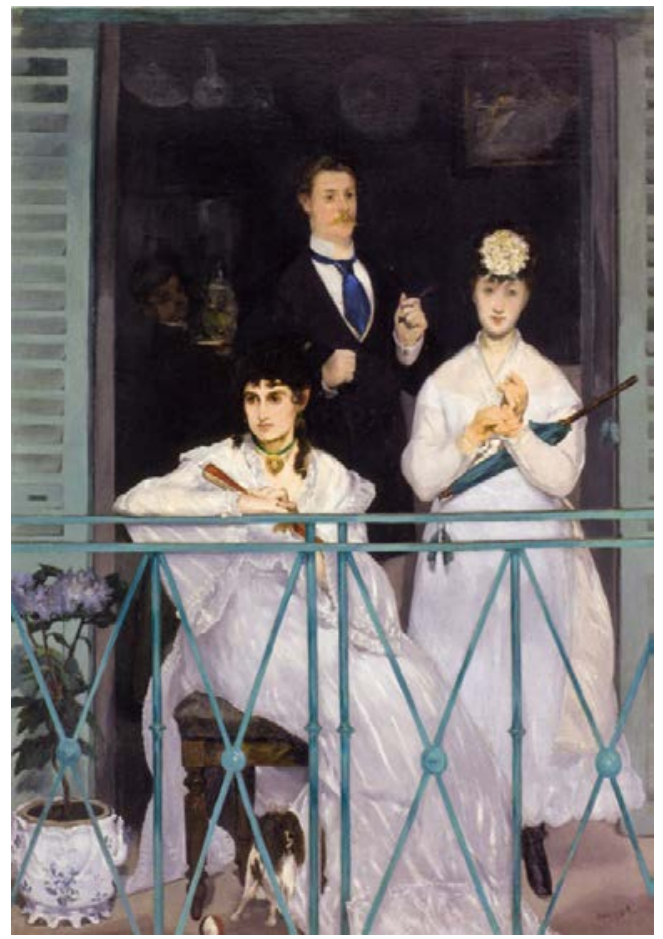

Figura 13

Édouard Manet, Le Balcon (1868-1869). Óleo sobre tela, $170 \times 124,5 \mathrm{~cm}$.

Fonte: Musée d'Orsay, Paris.

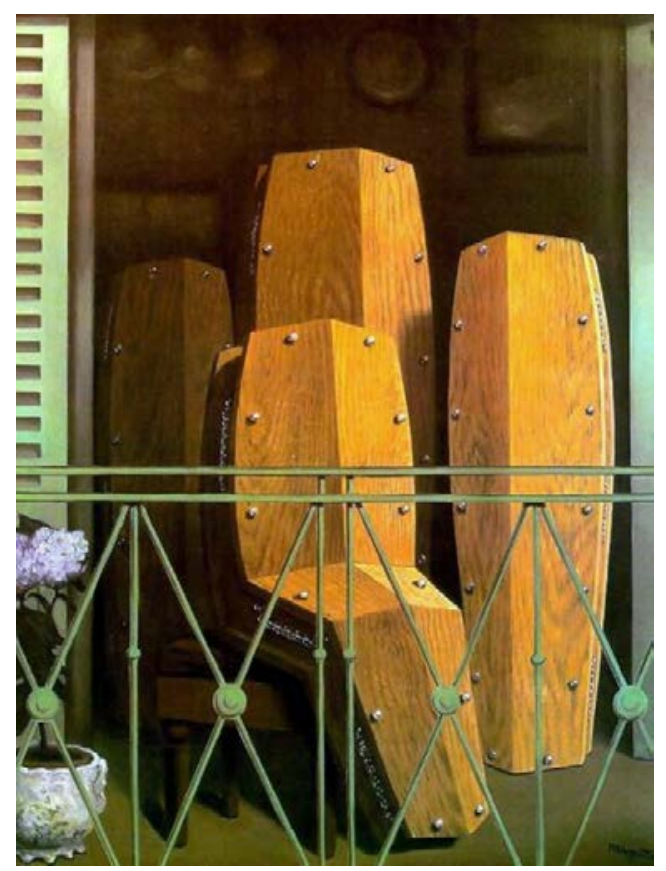

Figura 14

René Magritte, Perspective II: Le balcon de Manet (1950). Óleo sobre tela, $81 \times 60 \mathrm{~cm}$.

Fonte: Museum van Hedendaagse Kunst, Bélgica. 
As três figuras estão suspensas neste limiar de luz e sombra (Foucault, 2013b). Estas figuras que estão neste limiar olham para alguma coisa fora do balcão e este olhar é aquilo que constitui a invisibilidade. Para Foucault, a

invisibilidade é quase assinalada pelo fato de que as três figuras olham em três direções diferentes, todas as três absortas por um intenso espetáculo o qual, evidentemente, não podemos saber, porque para um ele está em frente da tela, porque para outro está à esquerda da tela e para o terceiro está à direita da tela (Foucault, 2013b, p. 71).

Se na Olympia o olhar (do observador), que atinge perpendicularmente a tela, produziu a visibilidade tornando visível a nudez do corpo da jovem, no Le Balcon o olhar foi imerso no espetáculo que se desenrola diante dos olhos. Cada um captura o "espetáculo" numa direção diferente que não converge para um ponto de fuga e por essa razão não constitui um objeto visível mas, inversamente, desdobra um espaço, assim como ocorre no olhar da menina no Le Chemin de fer (1872-1873) ou do homem bebendo cerveja ao balcão em La Serveuse de Bocks (1879). O olhar desdobra um espaço diante da superfície da tela que não se delimita. As diferentes direções formam um espaço múltiplo que dilata seus limites em composição com cada olhar e todos os olhares.

Foucault observa que, quase cem anos mais tarde, o pintor surrealista René Magritte pintou uma variação de Le Balcon (1868-1869) de Manet. O quadro Le Balcon de Manet (1950) de Magritte substitui as figuras humanas por caixões, acentuando a função limite que elas ocupavam no quadro de Manet - limite entre a luz e a sombra, entre a vida e a morte. A intensidade com que as figuras são arrebatadas por alguma coisa que ocorreu a sua frente produz um estado de absorção que as coloca sobre o fino fio da navalha em direção a um estado de pleno gozo (Foucault, 2013b).

Como vimos acima, a dimensão do limite evocada no olhar do olho arrancado pela transgressão que Bataille empreende em seus textos se impõe aqui novamente ao expor a brancura ocular em oposição à escuridão da cavidade craniana. O limite vertical no quadro Le Balcon também marca essa oposição limite que surge como fundamento da experiência de finitude, tal como a sentença nietzschiana que enuncia a morte de Deus abriu o caminho para qualquer limite na medida em que destituiu de seu posto o limite, por definição ilimitado, divino. Ela "delineia a nervura esquelética” (Foucault, 1963/1994, p. 235) da experiência contemporânea, da experiência do homem, que irradia luz ao tratar a experiência como pura impossibilidade. A experiência humana é dada enquanto possibilidade nesse espaço aberto pela morte de Deus. Dessa maneira, tal experiência pode ser compreendida somente na afirmação da sua finitude, e é no ato cuja experiência de desvelamento ocorre que o limite se impõe. Transgressão é, portanto, estar num mundo concebido pelo limite, como traço, como risco e como marca diante da ausência do sagrado. O esvaziamento de toda e qualquer positividade da dimensão transcendente significa profanar o vazio que se impõe e se recompõe em razão da morte de Deus.

Assim como a força visceral dos textos de Bataille manipula a luz de um olho que rasga a carne e eviscera o globular olho soberano do sujeito, assim é a pintura de Manet. Tal força imanente, assim como propõe Foucault, leva a literatura erótica a perverter a estrutura do corpo de modo a expor seu limite. A experiência da transgressão se configura quer pelo fato de estarmos situados no limite da linguagem, quer pela impossibilidade de inscrevermos a linguagem na palavra que, já por natureza, ultrapassa todas as palavras.

\section{O lugar do observador}

A terceira série de questões desenvolvida por Foucault diz respeito ao lugar do observador e para isso utiliza somente um quadro de Manet, Un bar aux Folies Bergère (1881-1882). O observador em verdade já apareceu nas discussões das duas rubricas anteriores. Na tela há um espaço entre a figura e o espelho, uma distância entre os dois que permite simultaneamente a visão da frente e das costas da personagem refletida. Este espaço entre as costas da personagem e o espelho tal como representado pela pintura até então será negado por Manet. Na verdade, neste quadro, Manet realizará uma "dupla negação da profundidade" (Foucault, 2013b, p. 74). Imediatamente atrás da mulher há um espelho em que se vê o que está diante da tela diferentemente do que se veria se o observador estivesse efetivamente diante do espelho. Não seria possível enxergar nem o reflexo da imagem das costas da moça nem aquilo que está atrás dela porque ela está perto demais do espelho e tal visão 
exigiria um inusitado deslocamento do observador para a direita. O observador deveria estar simultaneamente em frente da mulher e à direita. Tal operação fecha o espaço e nega a profundidade de antanho, como observado anteriormente a respeito da compressão da profundidade nas telas.

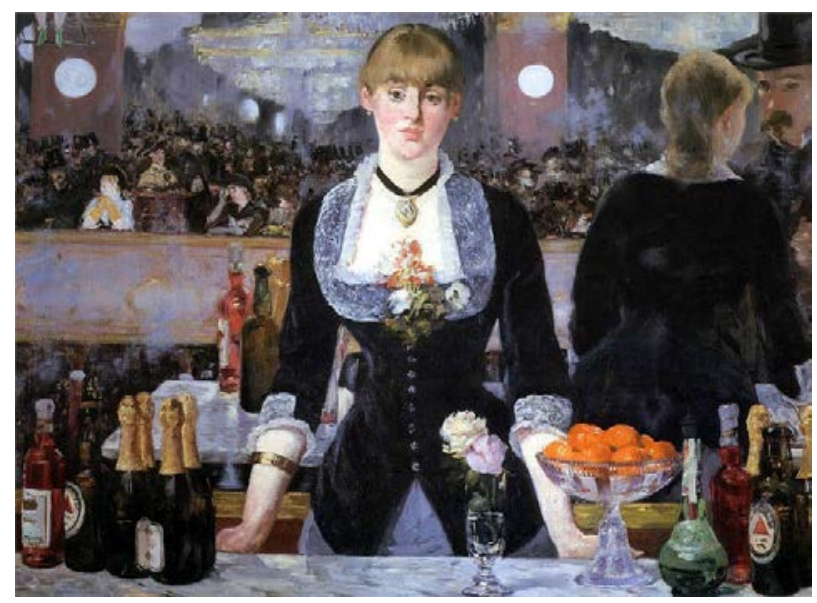

Figura 15

Édouard Manet, Folies Bergère (1881-1882).

Óleo sobre tela, $96 \times 130 \mathrm{~cm}$.

Fonte: The Courtlaud Gallery, Londres.

Todavia, juntamente com o espelho, o jogo da iluminação contribui para enfatizar o aspecto retangular da superfície da tela. Manet apresenta uma luz que incide perpendicularmente sobre a superfície da tela. Acabamos de ver na tela Olympia (1863) a incidência perpendicular da luz mas, no quadro Un bar aux Folies Bergère (1881-1882), há uma diferença importante: a luz e a iluminação que incidem perpendicular e diretamente sobre a tela estão ali reproduzidas e duplicadas pelo seu reflexo no espelho.

A reflexão figura o que está diante do espelho introduzindo uma significativa distorção na imagem. A grande distorção na imagem refletida da mulher é mais importante do que a correspondência da reflexão pontual dos elementos diante do espelho.

A figura da jovem retratada no quadro está de frente para o observador e, conforme falamos acima, em virtude de sua proximidade ao espelho a imagem de suas costas refletida não poderia ser vista pelo observador posicionado à sua frente. Curiosamente, o espelho mostra as costas de uma figura ligeiramente inclinada para a direita, visão que exigiria um deslocamento para a direita do observador. Há na tela dois lugares que não podem ser ocupados simultaneamente pelo próprio pintor: ou ele está em frente à mulher ou está à sua esquerda. Ou seja, para pintar o corpo da modelo de frente o pintor deve estar diante dela, mas para pintar a inclinação dada pelo reflexo no espelho o pintor precisará se movimentar proporcionalmente ao movimento no sentido contrário da inclinação. Este duplo posicionamento é incompatível com um único golpe de vista. Essa impossibilidade é uma espécie de presença e ausência do próprio pintor que tem o seu olhar representado numa direção e refletido noutra. A presença e a ausência do pintor estão simbolizadas pelo espaço vazio à esquerda da tela. Ao mesmo tempo, à direita, vemos a face de um homem voltada à garçonete e o olhar dele para a garçonete é lançado em uma perspectiva de cima para baixo. Tal operação mostra uma diferença de altura entre o observador e o pintor. A inconsistência que ora é presença ora ausência do lugar do próprio pintor faz com que não se possa definir precisamente o lugar em que está. Tal ação difere radicalmente do lugar estável em que o pintor se posiciona na tradição clássica da pintura. A tradição da pintura sempre determinou, principalmente com a utilização da perspectiva, a posição do pintor fixando o seu olhar e prolongando-o através das linhas que convergiam para um ponto no interior da tela.

Neste quadro, o jogo da presença e ausência cria um sistema de posicionamento triplo que é uma espécie de incompatibilidade espacial, no qual o pintor está em três posições diferentes e em nenhuma delas ao mesmo tempo. Na primeira posição o pintor está diante da jovem, frente à frente, e por essa razão não se pode ver a sombra de suas costas no espelho; na segunda posição o pintor, ocupando esta posição, tem seu reflexo no espaço vazio da tela, sendo que sua presença se dá na sua ausência; e, por último, na terceira posição ele ocupa a mesma posição que a figura que olha para a garçonete.

Vimos em Le Chemin de fer (1872-1873) este aspecto do espaço criado por Manet no qual o pintor faz com que o observador se movimente em torno do eixo vertical da superfície da tela como imagem-objeto. Aqui, esse jogo de presença e ausência produz um espaço em torno da superfície retangular que conduz o observador a se movimentar por ele.

A análise que desenvolvemos até agora destaca a questão do espaço na pintura de Manet e entrelaça diferentes questões: a materialidade da tela, a luz e 
a iluminação, o observador e o olhar. Olhar este que atravessa as três rubricas da análise foucaultiana e pode ser relacionado com outra discussão feita pelo filósofo francês acerca do espaço - a heterotopologia-, como veremos a seguir.

\section{Espaço heterotópico}

Na emissão radiofônica de 7 de dezembro de 1966, Foucault define a heterotopologia como a ciência dedicada aos espaços absolutamente outros dos que vivemos - os contra-espaços. As heterotopias se realizam, portanto, como contra-posicionamentos. Diferentemente da utopia que não se concretiza no espaço real da sociedade em que se vive, a heterotopia se realiza como contra-espaços numa sociedade e nenhuma sociedade se constitui sem estes espaços. O espaço heterotópico é repleto de relações, é o espaço de fora. Tanto a utopia quanto a heterotopia são posicionamentos capazes de contestar os espaços habitualmente vivenciados, de suspender ou até inverter as relações desenvolvidas por eles.

Encontramos na segunda emissão radiofônica (Foucault, 1984/1994) a descrição dos princípios da heterotopia. O primeiro princípio estabelece a constante produção de heterotopias em todo grupo humano. As sociedades ou grupos humanos sempre produzem espaços heterotópicos e metamorfoses destes espaços distribuídos em dois tipos: as heterotopias de crise biológica e as heterotopias de desvio. Na crise biológica, os indivíduos passam por um momento em que manifestam determinada experiência que deve ocorrer em outro lugar, em um lugar diferente dos espaços da vida em sociedade. São exemplos destes lugares os locais ocupados por mulheres parturientes, pessoas envelhecidas, adolescentes na puberdade e jovens no serviço militar obrigatório. As heterotopias de desvio são aquelas em que os indivíduos desviam da norma e são enviados para hospitais psiquiátricos, prisões etc.

Uma sociedade também pode fazer desaparecer ou aparecer uma heterotopia. As casas de prostituição foram ameaçadas de desaparecimento em inúmeros países europeus e o cemitério ocupou e ocupa um lugar heterotópico por excelência, tendo sofrido numerosas transformações que o fizeram aparecer de diferentes maneiras a partir da urbanização de Paris em meados do século XVIII. Em La naissance de la médicine sociale (1974/1994), Foucault mostra como o processo de transformação urbana de Paris produziu uma medicina social. Um dos objetivos da medicina urbana constituída no século XVIII diz respeito à análise do acúmulo do que poderia causar doença, ou seja, daquilo que agiria como fonte ou transmissor de epidemias ou endemias no espaço urbano. Com isso, a partir da segunda metade do século XVIII, encontra-se o deslocamento dos cemitérios para as partes periféricas do espaço urbano da cidade, ao mesmo tempo em que se inicia o esquadrinhamento do espaço desses: a individualização dos cadáveres, do caixão, das sepulturas familiares nos mausoléus reservados, o nome identificador de cada indivíduo morto etc. Esta individualização espacial tem justificativas político-sanitárias cujo objetivo é garantir a saúde dos vivos. Um conjunto de procedimentos de classificação detalhada forma os registros mortuários e incide sobre cada morto. Tal processo se cristaliza no século XIX. "Com efeito, é sob o reinado de Napoleão III que os grandes cemitérios parisienses foram organizados no limite das cidades" (Foucault, 2013a, p. 23).

O terceiro princípio afirma como regra da heterotopia a justaposição de vários espaços, que habitualmente são incompatíveis, em um lugar real. O recorte espacial do retângulo no qual a cena do teatro acontece inscreve diferentes lugares impossíveis de ocuparem aquele espaço retangular simultaneamente. De modo semelhante, o cinema inscreve artificialmente a tridimensionalidade projetada na superfície bidimensional. Os jardins são a heterotopia mais antiga. Segundo Foucault, nestes o mundo poderia ser representado na sua perfeição sagrada como um templo no qual as pessoas se encontram com esta plenitude. Se os jardins são reproduções do mundo, os tapetes são reproduções do jardim e, com o seu poder mágico de voar, o tapete mágico pode percorrer o espaço como um espelho móvel do jardim.

Este princípio da heterotopia articula-se ao espaço pictórico de Manet. "Em geral, a heterotopia tem como regra justapor em um lugar real vários espaços que, normalmente, seriam ou deveriam ser incompatíveis" (Foucault, 2013a, p. 24). Como vimos com Manet, o espaço produzido pela compressão do espaço pictórico clássico é intensificado até se tornar uma superfície. Esta superfície empurra a profundidade para "fora" da tela. Tal operação engendra e torna visível o espaço. Ele é uma heterotopia porque coloca em questão o espaço da experiência ordinária; ele questiona o espaço da percepção no qual supomos e organizamos a nossa vida cotidiana, estabelecendo 
um jogo de sobreposições ou de possibilidades de sobreposições e convivências. O espaço atravessado pelo eixo recto verso compreende tanto a iluminação e a fonte desta iluminação, pois ela incide frontalmente na tela, quanto o observador da pintura, podendo ambos coexistir neste espaço. Ao se posicionar neste espaço, o olhar observador está sobreposto à iluminação e está simultaneamente implicado na pintura. Em Olympia a nudez é revelada pelo olhar do observador conferindo consistência ao espaço heterotópico.

O penúltimo princípio das heterotopias é frequentemente ligado a recortes temporais. As heterotopias eternas realizam uma acumulação permanente do tempo por meio das bibliotecas e museus. Este princípio está presente na pintura de Manet na medida em contribuiu para a transformação da pintura de museu, da picturialização da superfície disposta em paredes dos museus. Como afirmamos anteriormente, a pintura de Manet produz uma imagem-objeto e transforma o museu em um espaço que expõe e acumula numerosas superfícies picturializadas. Sem revelar significados ou acabamentos orientados pela tradição escolar, a pintura orienta a sua presença articulada ao olhar. As bibliotecas estancarão o tempo aprisionando infinitamente (guiadas pelo desejo de aprisionar) todas as épocas e culturas em um incomensurável arquivo para além do tempo.

É bem possível que Le dejeuner sur l'herbe e Olympia tenham sido as primeiras pinturas "de museu": pela primeira vez na arte europeia, telas foram pintadas - não exatamente para reproduzir Giogione, Rafael e Velázques, mas para expressar, ao abrigo dessa relação singular e visível, sob essa decifrável referência, uma relação nova [e substancial] da pintura consigo mesma, para manifestar a existência dos museus e o modo de ser e de parentesco que os quadros adquirem neles. Na mesma época, La tentation é a primeira obra literária que leva em conta essas instituições imaturas nas quais os livros se acumulam e onde sutilmente cresce a lenta, a indubitável vegetação de seu saber. Flaubert é para a biblioteca o que Manet é para o museu. Eles escrevem, eles pintam, em uma relação fundamental com o que foi pintado, com o que foi escrito - ou melhor, com aquilo que da pintura e da escrita permanece perpetuamente aberto. Sua arte se erige onde se forma o arquivo. Não absolutamente que eles assinalem o caráter tristemente histórico - juventude encurtada, ausência de frescor, inverno das invenções - pelo qual gostamos de estigmatizar nossa época alexandrina; mas eles fazem emergir um fato essencial em nossa cultura: cada quadro pertence desde então à grande superfície quadrilátera da pintura; cada obra literária pertence ao murmúrio infinito do escrito. Flaubert e Manet fizeram existir, na própria arte, os livros e as telas (Foucault, 1964/1994, pp. 298-299).

As heterotopias crônicas possuem a fugacidade do acontecimento no tempo: a festa, cuja temporalidade passageira reúne a heterogeneidade na sua existência. Assim, as feiras acontecem como lugares periféricos à cidade com a circulação passageira de produtos, objetos e pessoas. As colônias de férias em ilhas e praias paradisíacas por um lado permitem um reencontro com a humanidade na nudez primitiva interdita aos que vivem nas cidades e assim estão próximas dos museus e bibliotecas na "utopia de eternidade"; por outro lado, são a própria negação da eternidade quanto mais parecem promover um apagamento do tempo, um retorno à nudez originária. Foucault enfatiza a existência de lugares de passagem no século XIX, lugares para se tornar outra coisa, como a passagem da criança para o adulto.

O quinto e último princípio diz respeito à abertura e entrada em uma heterotopia. Entra-se em uma heterotopia por obrigação ou por submissão. As heterotopias possuem sistemas de abertura e fechamento - ritos de passagem, de iniciação, purificações, prisões - que a isolam do resto do espaço. $\mathrm{O}$ ingresso no espaço da prisão provém de uma submissão, e este está isolado do restante do espaço que o circunda. Os ritos e a purificação submetem os corpos a lugares religiosos, de higienização, como os banhos turcos muçulmanos ou as saunas escandinavas.

Na Roma imperial, existiam, de fato, bordéis, bairros de prazer, zonas criminais etc., assim como uma espécie de lugar de prazer quase público: os banhos, as termas. Estas eram um lugar de prazer e de encontro muito importante que, progressivamente, desapareceu na Europa. Na Idade Média, as termas eram ainda um lugar de encontro de homens entre si e das mulheres entre si, embora disso se fale raramente. O que foi falado e condenado, mas também experimentado, foram 
os encontros entre homens e mulheres, que desapareceram ao longo dos séculos XVI e XVII (Foucault, 1982/1994, pp. 280-281).

A sauna no século XIX em França constituía formas de sociabilidade como "catedral de prazer no coração da cidade" (Foucault, 1982/1994, p. 218) que, entre seus prazeres, incluía o sexo. Os bordéis também estão ligados a este princípio heterotópico por comunicar os homens por meio das mesmas mulheres e de infecções e doenças. Tal processo contagioso engendra sociabilidade: ele produz certa solidariedade entre pessoas que ingressam no espaço heterotópico. Ao desfrutar dos prazeres do sexo, a solidariedade infecciosa sustenta a sociabilidade.

Na entrevista dada a Paul Rabinow, em 1982, Foucault define as heterotopias como: "os espaços singulares que encontramos em alguns espaços sociais cujas funções são diferentes das de outros, até mesmo diretamente opostas" (1982/1994, p. 219). Estudar efetivamente os espaços é produzir uma analítica do poder inscrito na sua dimensão histórico-política. Desta forma, "O espaço é fundamental em toda forma de vida comunitária. O espaço é fundamental em todo o exercício do poder" (1982/1994, p. 282). Reiteramos aqui a proposição exposta no início deste trabalho, a saber, a de que Foucault encontrou o ponto nodal daquilo que procurava - "as relações que podem existir entre poder e saber" (1976/1994, p. 33) - a partir de suas “obsessões espaciais". Ao pensarmos a espacialização do poder, as heterotopias aparecem como espaços que contestam todos os outros espaços. Contestam por duas razões. Primeira razão: as heterotopias produzem uma ilusão de que toda a realidade distinta da heterotopia é ilusória. Segunda razão: as heterotopias produzem um lugar perfeitamente ordenado que aponta para a imperfeição da sociedade na qual se vive.

\section{Considerações finais}

O objetivo deste artigo consistiu em demonstrar como o olhar e o espaço próprios à pintura de Manet estabelecem heterotopias. O entrelaçamento do espaço com o olhar é exposto pela análise de três rubricas da pintura de Manet: a superfície da tela, a luminosidade e o observador. Segundo a leitura de Foucault, o espaço pictórico em Manet se configura como um espaço que não se efetua na experiência ordinária, mas na experiência de estranhamento do espaço imediato ou do espaço da representação.

As relações de poder se realizam na produção do espaço que aparece no jogo da visibilidade e da invisibilidade (Foucault, 1977/1994a,1977/1994b). Tal relação intrínseca entre poder e espacialidade considera o poder como o jogo de forças que se configura entre pontos, isto é, que configura uma espacialidade, dialogando com as questões elaboradas sob a noção de heterotopia. E encontramos ressonância disto na interpretação da obra de autores da literatura, da poesia, da fotografia, do cinema e da música contemporânea que atravessam a obra de Foucault em toda a sua extensão. Textos, conferências, artigos e entrevistas de Foucault são frequentemente negligenciados em detrimento da leitura dos livros do autor centrados em questões epistemológicas ou nas questões do poder disciplinar e biopolítico. Para nós, contudo, conforme demonstrado neste artigo, as discussões estéticas estão indissoluvelmente ligadas às análises do poder. A análise aqui realizada visa tornar porosas as cisões consolidadas por certa leitura da obra de Foucault e reduzir distanciamentos entre a produção artística, filosófica, histórica, política ou do espaço social. Portanto, pensar os efeitos políticos do espaço e seus outros, assim como da produção artística, pavimenta um caminho possível que esboça novas compreensões das relações dos corpos com os enraizamentos espaciais e seus desdobramentos subjetivos singulares.

\section{Referências}

Alberti, L. B. (2009). Da pintura. Campinas, SP: Editora da Unicamp.

Bourriaud, N. (2013). Introduction. In M. Foucault, Manet and the object of painting(pp.7-19). London: Tate Publishing.

Calomeni, T. (2013). Notas sobre o escândalo e o cinismo de Manet. Viso: Cadernos de Estética Aplicada, 7(13), 131-147. http://www.revistaviso.com.br/pdf/Viso_13_TerezaCalomeni.pdf

Calomeni, T. (2015). Foucault, Velázquez, Manet. Viso: Cadernos de Estética Aplicada, 9(16), 73-102. http://www. revistaviso.com.br/visArtigo.asp?sArti=166

Defert, D. (2013). Hétérotopie: tribulations d'un concept entre Venise, Berlin et Los Angeles (postface). In M. Foucault, Le corps utopique, les hétérotopies (pp. 07-55). São Paulo, SP: N-1 Publications. 
Foucault, M. (1963). Raymond Roussel. Paris: Gallimard.

Foucault, M. (1966). Les mots et les choses. Paris: Gallimard.

Foucault, M. (1989). La peinture de Manet. Revue des Sciences Humaines: Les Cahiers de Tunisie, 39(149-150), 61-89.

Foucault, M. (1994). Préface à la transgression. In D. Défert \& F. Ewald (Orgs.), Dits et écrits (Vol. 1, pp. 233- 250). Paris: Gallimard. (Trabalho original publicado em 1963)

Foucault, M. (1994). Postface à Flaubert (G.). In D. Défert \& F. Ewald (Orgs.), Dits et écrits (Vol. 1, pp. 29-325). Paris: Gallimard. (Trabalho original publicado em 1964)

Foucault, M. (1994). La pensée du dehors. In D. Défert \& F. Ewald (Orgs.), Dits et écrits (Vol. 1, pp. 518-539). Paris: Gallimard. (Trabalho original publicado em 1966)

Foucault, M. (1994). La force de fuir. In D. Défert \& F. Ewald (Orgs.), Dits etécrits (Vol. 2, pp. 401-405). Paris: Gallimard. (Trabalho original publicado em 1973)

Foucault, M. (1994). La naissance de la médecine sociale. In D. Défert \& F. Ewald (Orgs.), Dits et Écrits (Vol. 3, pp. 207-228). Paris: Gallimard. (Trabalho original publicado em 1974)

Foucault, M. (1994a). À quoi rêvent les philosophes? In D. Défert \& F. Ewald (Orgs.), Dits et Écrits (Vol. 2, pp. 704-707). Paris: Gallimard. (Trabalho original publicado em 1975)

Foucault, M. (1994b). La peiture photogénique. In D. Défert \& F. Ewald (Orgs.), Dits et écrits (Vol. 2, pp. 707-715). Paris: Gallimard. (Trabalho original publicado em 1975)

Foucault, M. (1994). Questions à Michel Foucault sur la géographie. In D. Défert \& F. Ewald (Orgs.), Dits et écrits (Vol. 3, pp. 28-40). Paris: Gallimard. (Trabalho original publicado em 1976)

Foucault, M. (1994a). L’oeil du pouvoir. In D. Défert \& F. Ewald (Orgs.), Dits et écrits (Vol. 3, pp. 190-207). Paris: Gallimard. (Trabalho original publicado em 1977)

Foucault, M. (1994b). Pouvoir et savoir. In D. Défert \& F. Ewald (Orgs.), Dits et écrits(Vol. 3, pp. 399-414). Paris: Gallimard. (Trabalho original publicado em 1977)

Foucault, M. (1994). Espace, savoir et pouvoir In D. Défert \& F. Ewald (Orgs.), Dits etécrits (Vol. 4, pp. 270-285). Paris: Gallimard. (Trabalho original publicado em 19682)

Foucault, M. (1994). Des espaces autres. In D. Défert \& F. Ewald (Orgs.), Dits et écrits (Vol. 4, pp. 752-762). Paris: Gallimard. (Trabalho original publicado em 1984)

Foucault, M. (2010) A arqueologia do saber. Rio de Janeiro, RJ: Forense Universitária.

Foucault, M. (2013a). Le corps utopique, les hétérotopies. São Paulo, SP: N-1 Publications.

Foucault, M. (2013b). Manet and the object of painting. London: Tate Publishing.

Foucault, M. (2014). Isto não é um cachimbo. São Paulo, SP: Paz e Terra.

Rajchman, J. (1988). Foucault's art of seeing. October, (44), 88-117.

Santos, M. S. (2011). Imagens do pensamento: A pintura de Édouard Manet e Gérard Fromanger na obra de Michel Foucault (Dissertação de mestrado). Pontifícia Universidade Católica de São Paulo, São Paulo, SP.

Shapiro, G. (2003). Archaeologies of vision: Foucault and Nietzsche seeing and saying. Chicago: The University of Chicago Press.

Schapiro, M. (2011). Modern Art 19th and 20th Centuries: selected papers. New York: George Braziller.

\section{Rômulo Ballestê}

Doutor pelo Programa de Pós-graduação em Psicologia da Universidade Federal do Rio de Janeiro, Rio de Janeiro RJ. Brasil. Professor da Universidade Federal de Mato Grosso do Sul - MS. Brasil.

E-mail: romulo.balleste@ufms.br

(1) https://orcid.org/0000-0003-1511-1304 
Psicologia: Ciência e Profissão 2020 v. 40, e191649, 1-18.

\section{Francisco Teixeira Portugal}

Doutor pela Pontifícia Universidade Católica do Rio de Janeiro. Professor da Universidade Federal do Rio de JaneiroRJ. Brasil.

E-mail: fportugal@ufrj.br

(1) https://orcid.org/0000-0001-6481-6509

Endereço para envio de correspondência:

Av. Pasteur, 250, Urca. CEP: 22290-240. Rio de Janeiro - RJ. Brasil.

Recebido 16/02/2018

Aceito $12 / 11 / 2018$

Received 16/02/2018

Approved 12/11/2018

Recibido 16/02/2018

Aceptado 12/11/2018

Como citar: Ballestê, R. M. S., \& Portugal, F. T. (2020). Olhar e Espaço como Heterotopia na Pintura de Manet: uma Leitura de Michel Foucault. Psicologia: Ciência e Profissão, 40, 1-18.

https://doi.org/10.1590/1982-3703003191649

How to cite: Ballestê, R. M. S., \& Portugal, F. T. (2020). Glance and Space as Heterotopy in Manet's Painting: a Michel Foucault’s Reading. Psicologia: Ciência e Profissão, 40, 1-18.

https://doi.org/10.1590/1982-3703003191649

Cómo citar: Ballestê, R. M. S., \& Portugal, F. T. (2020). Mirada y Espacio como Heterotopía en la Pintura de Manet: uma Lectura de Michel Foucault. Psicologia: Ciência e Profissão, 40, 1-18.

https://doi.org/10.1590/1982-3703003191649 